\title{
The Element of 'Access to Information' in Arhus Convention and Act Regarding Dissemination and Free Access to Information
}

\author{
Seiyed Asghar Sajjadi ${ }^{1} \&$ Mohammad Hossein Ramazani Ghavamabadi ${ }^{1}$ \\ ${ }^{1}$ Department of Environmental Law, Law Faculty, Shahid Beheshti University, Tehran, Iran \\ Correspondence: Mohammad Hossein Ramazani Ghavamabadi, Department of Environmental Law, Law \\ Faculty, Shahid Beheshti University, Tehran, Iran. E-mail: ramazanighavam@yahoo.com
}

Received: January 21, 2016 Accepted: February 16, 2016 Online Published: March 31, 2016

doi:10.5539/jpl.v9n2p103 URL: http://dx.doi.org/10.5539/jpl.v9n2p103

\begin{abstract}
The free access of all people to information is deemed as the requisite and precondition for efficient participation in process of decision-making by public authorities where it has been reflected in many national and international rules and regulations.

'The right of access to information that has been formally recognized in many countries by virtue of criteria in constitution or articles of freedom of information law as a right includes most of the information stored by public authorities and consists of environmental information. The regulations regarding recognition of right of litigation for citizens may also include some regulations that give citizens the right of acquisition of essential information.

Before entry in domain of environmental terminology, the concepts of access to information and public participations are assumed as a category in political law that has been reflected in democratic political regimes under title of 'Rights of nation' in constitutions of those countries.'
\end{abstract}

Access to information etc has been formally recognized in Article 10 of Rio Declaration on Environment and Development (1992) at international level and it briefly holds: '.. . Anyone shall totally access to the information at disposal of public institutions about environment and ... the governments shall facilitate public participation by giving information to the people... and compensation for loss shall be guaranteed.'

Although access to information and other aforesaid issues are not deemed as new elements in Article 10 of Rio Declaration (1992) and they have been typically incorporated in some other international documents several years before 1992, Aarhus Convention (1998) has explored in details of totally triple concepts in Article 10 at regional level and it presents specific mechanism for enforcement of regulations in this convention.

UN Economic Commission for Europe ... was inaugurated in Aarhus (Denmark) on 25 June 1998 and Aarhus Convention ... was approved. Iran Islamic Parliament also ratified Act regarding Dissemination and Free Access to Information on January 252009 and it was recognized in compliance with expediency of system.

This article examines and compares Aarhus Convention because of it remarkable importance as a model for access to information and its executive mechanism for element of access to information in that convention and Act regarding Dissemination and Free Access to Information so that by means of comparative study on these two documents concerning to element of access to information it can give answer to this proposed question that if Act regarding Dissemination and Free Access to Information may be responsive to public information requirements about the environmental subjects in such a way that to prepare the ground and possibility for public participation in process of environmental decision-making by the public authorities as it reflected in Aarhus Convention.

After review and comparison of information in terms of great constraint and banning in presentation of information titled as 'confidential' that has been reflected and executed, the size and subject of accessible information may not meet the requirements of community at the age of explosion of information and in the world that has been converted into a small village. On the other hand, only Iranian nationals have right to access this information and discrimination in nationality is another main barrier against public access to information. To remove this inadequacy and defect, the upgraded laws should be enacted through exploitation from regulations and mechanisms of Aarhus Convention as the world pattern. Among them, the confidential (classified) information size may be noticeably reduced and the persons will have right of access to useful information 
without discrimination in nationality.

Keywords: public participation, assessment of environmental consequences, Rio Declaration, Aarhus Convention

\section{Introduction}

At the end of 1960s, following to warning of danger by scientists, the public opinion was extremely excited toward the risks that threatened the vital layer. This movement was widely deep-rooted at international level and it became consolidated and firmed from the start point. ${ }^{1}$

It was from now on that the attitude and treatment with environmental problem was totally changed and it gradually formed international and world shape under the pressure of public opinion and the environment was proposed as a system. The legal texts were increased for environmental protection at domestic level and the governments created special administrative institutions to cope with pollution. Also the international organizations, in turn, indicated suitable and strong reaction versus the new mentioned issues and a new chapter opened. $^{2}$

The inadvertent exploitation from natural resources, destruction of ecosystems and land and marine habitats, erosion of ozone layer, leaking of gas in Indian Bhopal Factory, explosion in Chernobyl nuclear power plant in Ukraine (former soviet Union), accident of Torrey Canyon oil tanker, and alarming by scientists for this point that environmental protection is assumed as an international responsibility and it does not matter through which border the given environmental elements are placed have made world public opinion as worried and frightened.

In exposure to enormity and emergency of such international environmental problems and issues the world has exercised political awakening. ${ }^{3}$

This issue dubbed importance for access to environmental information several times.

The concept of information in phrase 'freedom of information' covers all records, documents, and evidences are archived in one public unit regardless of form of saving and storage (document, tape, electronic recorder and the like), irrespective of source (if it is presented by a public authority or other officials), and regardless of date of production. ${ }^{4}$

The Right of awareness may denote freedom in looking for information as a restricted and limited concept and or it means right of access to information and right of acquisition and receiving that concept based on its extended meaning. The government's requirement for dissemination information about public plans and projects may upgrade public knowledge. Pressure on government under title of a task for dissemination of information etc leads to public awareness widely and it acts as a basis for informed decision making. ${ }^{5}$

For example, Japanese Supreme Court (1969) has assumed right of knowledge included in predicted supports and guarantees in Article 21 of constitution for freedom of expression. In 1989, Indian Supreme Court put access to governmental information as the integrated element of fundamental right in respective of freedom of expression that has been anticipated in Article 21 of constitution. ${ }^{6}$ The human rights texts mainly include right of freedom of information and governmental mutual task for communication. The right on information has been anticipated in Article 19 of Universal Declaration of Human Rights, Clause II of Article 19 in International Covenant on Civil and Political Rights, and Article 10 of Inter- American Declaration of Rights and Duties of Man. ${ }^{7}$ Similarly, it has been reflected in Article 10 of European Convention on the protection from Human Rights and Fundamental Freedom (Rome, 1950) ${ }^{8}$, Article 13 of American Convention on Human Rights (San Jose $)^{9}$, and African Charter on the Rights and Duties of people (1981) where in Clause I of Article 9 it explicitly

\footnotetext{
1 - Kiss, Alexander eta 1, Environmental laws, transl. Habibi Mohammad Hassan, vol. 1, Tehran University Publication, 2005: 25

2 - Amir Arjomand, Ardeshir, Environmental protection and international correlation, Journal of legal studies, Tehran University of Shahid Beheshti, vol. 73, 15-74, p 33

3 - Mousavi, Seyed Fazlollah, International environmental law, Mizan Pub, Tehran, 2001, p 30

4 - Ansari, Bagher, Mass media rights, SAMT Pub, Tehran, 2011, p 40

5 - Guendling Lothar et al, Environmental rights, transl. Habibi Mohammad Hassan, 2 ${ }^{\text {nd }}$ vol., Tehran University Pub, 2002, pp 309-310

${ }^{6}$ - Ansari, Bagheri, Freedom of information, Dadgostar Pub, Tehran, 2008, p 64

7 - Shelton, Dina \& Kiss, Alexander, ibid, p 85

8 - Zamani, Seyed Ghasem et al, Regional supporting institutions and mechanisms from human rights, Shahr-E-Danesh Pub, Tehran, 2007, p 270

9 - Ibid, p 299
} 
holds: 'Any individual shall have right for receiving information. ${ }^{10}$,

Texts of regional human rights comprise of relevant instructions to right of acquisition of information or similar tasks for governments. Generally, European governments shall guarantee freedom of access to information by virtue of Article 10 of European Convention on Human Rights. ${ }^{11}$

Also judicial procedure asserts generally on right of information and particularly on right for access to environmental information. For instance, Bombay Supreme Court (1986) issued award in favor of right of social activity groups to acquire information. ${ }^{12}$ In this case, the court held that right on information originates from right of freedom of speech and expression that was guaranteed by constitution. Often beneficiary parties have complained in courts to take judicial order for disclosure of information and documents. ${ }^{13}$

Access to information about environmental subjects has been implied in Article 10 of Rio Declaration (June, 1992) as environmental tool and it holds:

'Environmental issues are the best- handled with the participation of all concerned citizens at the relevant level. ... At the national level, each individual shall have appropriate access to information concerning the environment that is held by public authorities, including information on hazardous materials and activities in their communities, and the opportunity to participate in decision- making process. State shall facilitate and encourage public awareness and participation by making information widely available... ${ }^{14}$

It noteworthy that Article 10 of Rio Declaration is not the only document that emphasizes in importance of element of access to environmental information, but one can refer to other documents such as Agenda-21, United Nations Millennium Development Goal and World Summit on Sustainable Development (WSSD) plan of implementation regarding project of execution of sustainable development as well.

With respect to environmental crisis and disastrous world accidents that are followed by destruction of environment and removal of irreversible natural resources, the concern for efficient execution of environmental laws of human rights and creating appropriate mechanism caused United Nations Economic Commission for Europe to be held in forth conference of ministers in Europe in June 1998 in response to concerns and premonitions of world people under title of 'Environment for Europe' and Aarhus Convention approved a declaration regarding access to information, public participation in decision-making and access to justice relating to environmental issues. ${ }^{15}$

Aarhus Convention is the first multilateral environmental agreement that mainly aims at loading some obligation to both parties about citizens. ${ }^{16}$ In preamble of this convention, it addresses first article of Stockholm Declaration about human environment, Article 10 of Rio Declaration regarding environment and development and element of access to information, and Resolutions No 37/7 dated $28^{\text {th }}$ October 1982 concerning world charter for nature, and No 54/94 dated December 141990 about healthy environment for welfare of members of General Assembly. ${ }^{17}$

Although the convention is a regional and European document, by virtue of Article 19 of Clause III, the convention opens for joining any government rather than those governments were mentioned in Clause II provided that it is a member in UN after approval of assembly of members. ${ }^{18}$

In terms of importance noticeable international importance of Aarhus Convention as a world model with internet information website that discusses about element of availability to information more comprehensively than any other environmental document that has been already ratified by specific executive mechanism, the author intended to conduct comparative study on element of availability to information in Aarhus Convention (1998)

\footnotetext{
10 - Ibid, p 322

11 - Guendling,

12 - Bombay Environment Action Group Shaym Hk Chainani Iindian Inhabitant, Save Pune Citizens Committee V. Pune

Cantonment Board, High Court of Bombay, Writ Petition No.2733 of 1986.

13 - Shelton, Dina \& Kiss, Alexander, pp 84-85

14 - Human rights studies center, An abstract of the foremost international human rights documents, Faculty of law and political sciences, Tehran University, 2003, p 219

15 - Irish Environment Network http//ien.ie

16 - Palmers, Mark, Regulation of environmental rights, review on Aarhus Convention, transl. Mashhadi Ali, Legal Journal of Davar (Arbiter), Law faculty, Shahid Beheshti University, Vol. 2, p 320

17 - Convention on Access to information, public participation in Decision- making and Access to justice in Environmental matters. done at Aarhus, Denmark ,on 25 June 1998.

18 - Ibid, Article 19
} 
and Act regarding dissemination and free access to information approved by Islamic Iran Parliament (2008). Although it is an absolute and general document thereby one can find better the weak and strong points of these two documents by comparison of them with each other.

Act regarding dissemination and free access to information was approved by Islamic Iran Parliament on $25^{\text {th }}$ January 2009 and it was recognized in conformity to expediency of system by Expediency Council. This issue implies opposition of Guardian Council to the aforesaid law.

With a little glance at aforementioned law it is observed that the exceptions for access to information mainly include the classified documents and data (governmental secrets) that are based on Act regarding punishment for dissemination and disclosure of confidential and secret documents of government and this has been approved by legislation parliament 34 years ago in 1974. However, IRI Constitution (approved in 1979) is silent to access to information. In this regard and with resort to the extended interpretation of some articles in IRI Constitution including Article 3 that it assumes public participation of people in determination of their political and economic fate etc as right of people and or Article 50 in which it notifies environmental protection and rights of current and post generations as a public task and forbids any destructive economic activity in environment and also Article 100 in which it addresses administration of councils in advancement of economic and social plans etc and at the same time with respect to legal rule of 'quando aliquid mandatur, mandatur et omne per quod pervenitur ad illud' (permission for parts applies to permission for the whole means) one may probably infer that availability element to the relevant information is latent in texts of the aforesaid articles.

However, World Declaration on Human Rights, international covenant on civil and political rights, American convention of rights and tasks of peoples, and European convention for human's rights and freedoms are predicted as a triple regulation for ascertainment of legitimacy of the imposable constraints to freedom of expression and information. The first part of this regulation notifies that any type of constraint shall be stipulated only according to law. Secondly, creating any constraint should be for the sake of one of the legitimate objectives explicitly embedded in law. Thirdly, it shall be proved that stipulation of the given constraint is necessary. ${ }^{19}$

Now in national executive system over the time and as the consequence of bureaucratic administrative system it is mainly imagined that the lack of communication is assumed as basis. Lack of communication regarding some of public institutes is to the extent that they reject even from dissemination their related rules and regulations which may create public rights and obligations; for example, they classify the laws approved by the parliament!

Or they may classify foreign journal that people can prepare them from newspaper kiosks! Now, there is few numbers of employees who believe that information belongs to people and it should be put at disposal of applicants. ${ }^{20}$

With respect to importance Arhus Convention and aforesaid explanation and universal model in this study, the element of access to information has been explored in the given convention and Act regarding dissemination and free access to information and through expressing weak and strong points of that subject we give answer to this question that if Act regarding dissemination and free access to information may protect from environment and rights of current and post generations.

In response to this question we imply that it seems with respect to denotation of the aforesaid Act regarding access to information and mass of the related exceptions for the information which may be presented by public authorities titled as confidential and secret, it is not responsive to information requirements for environmental protection and although Aarhus Convention is exclusively an environmental document, in terms of comprehensiveness and pervasiveness of its regulations about the element of access to information and executive and regulatory mechanisms regarding enforcement of regulations of this convention it is an appropriate pattern that its regulations may be exploited highly and preciously in position for pervasive legislation with strong sanctions regarding free access to information in various fields and including environmental issues and even to join it in environmental domain.

\section{Background and Way of Formation}

Either of Arhus Convention approved in UN Economic Committee for Europe and or Act regarding Dissemination and Free Access to information ratified by Islamic Iran Parliament, in turn, has formed according to contextual basis and in specific form.

\footnotetext{
19 - Ansari, Bagher, ibid, pp 155-156

${ }^{20}$ - Ibid, p 20
} 


\subsection{Background to Form Aarhus Convention}

Recent discovery of an Ozone Layer in atmospheric stratosphere ... caused paying attention and considering the evidences about the relevance of destruction of ozone layer along with rising incidence of skin diseases, cancer, cataract, and breakdown the (body) immunity system, and destroying the crops and products. ${ }^{21}$

The extraordinary population growth had extremely destroyed that negative consequences of inadvertent use of technology and consuming fossil energy of earth planet and humans are the main factors for these damages. Following to warning of scientists, public opinion showed growing reaction toward environmental protection per se. $^{22}$

There are few books that have changed the historical path. Book of 'Silent Spring' written by Rachel Carson is also one of the other books of this type. The contemporary environmental movement started with this book that has certainly affected on social polices of any nation. ${ }^{23}$

This implies ever-increasing importance of access to environmental information of any type. In fact, Arhus Convention was a response to serious concerns and premonitions toward damaging of environment.

United Nations Economic Committee for Europe was established in forth conference of European ministers with participation of member states in Arhus Denmark on $25^{\text {th }}$ June 1998 and approved a convention about access to information, participation in making decision, and access to justice regarding environmental issues.

This convention became mandatory on $30^{\text {th }}$ October 2001. At present (2014), it includes 44 members comprising of European Union (EU). The member states in this convention mainly include the countries in central and Eastern Europe, central Asia, and Caucasian region. ${ }^{24}$

Although this convention was proposed throughout Europe and within framework of procedures and political formalities for environmental collaborations in Europe... but this document does not only belong to European region and it is open for joining of all member states in UN ) provided approval by members). ${ }^{25}$ It is implied in Article 19 in Clause III of this convention that 'Any other state, not referred to in paragraph 2 above (reflected in Article 17), that is a member of United Nations may accede to the convention upon approval by the meeting of the parties. ${ }^{26}$

The first meeting of member states in Aarhus Convention was held in Lucca (Italy) on 21-23 October 2002 and in addition to Lucca Resolution the result of this summit included proposal of guidance for access to information, participation and access to court with respect to genetically modified organizations, and Aarhus rules of procedure. ${ }^{27}$

The extraordinary meeting of this convention was held in Kiev at Ukraine on 21 May 2003 and the protocol for release of pollutants and transfer registers were also ratified in that summit. This protocol holds: In order to improve public awareness and access to the relevant information to pollutants which are disposed within the extent of living place of a nation and or passed through it the processes of release of pollutants and transferring them by industrial sources and other sources shall be recorded and put at public disposal. It is noteworthy that even those states which are not members in Aarhus Convention and European Economic Commission may joint to this protocol.

The second session of this convention was held in Almaty (Kazakhstan) dated 25-27 May 2005 and Aarhus Convention was amended and new regulations were codified concerning public participation in decision- making process about intentional release of genetically modified microorganisms. ${ }^{28}$

The convention has transferred the regulations, which have already existed at national level, to international level. Most of conventions, which have typically mentioned some issues about access to information, had already existed before approval of convention such as Rio Declaration in which Article 10 is concerned with access to

\footnotetext{
21 - Mousavi, ibid, p 29

22 - Amir Arjomand, Ardeshir, ibid, pp 327-330

${ }^{23}$ - Carson, Rachel, Silent spring, transl. Vahabzadeh Abdul Hossein et al, Mashhad Academic Jihad Pub, 2014, pp 5-6

${ }^{24}$ - irich Environment Network Http:// ien.ie

25 - Palmers, Mark, ibid, p 338

26 - Aarhus, Convention on access to information, public participation in Decision-making and access to justice in

Environmental matters. Done at Aarhus, Denmark, on 25 June 1998.available at: www.Unece.org/pp/acig.pdf.

27 - http:// www.Unece.org/ env/pp / prtr. Him.

28 - Ibid
} 
information etc. such conventions have existed both in Europe and in international level. ${ }^{29}$

\subsection{Formation of Act Regarding Dissemination and Free Access to Information}

The subject of access to information has not been mentioned in each of principles of IRI Constitution. But in Article 3 in order to express providing of all governmental facilities to achieve the reflected goals in Article-2, it refers to some activities which are about introducing bases and cornerstones of system including in Clause VIII it deals with public participation by people in determination of their own political, economic, social, and cultural fate. Access to information is related to any subject as precondition for participation in that activity and participation will be subjected to rejection of that matter without equipping with information. Whereas public participation of people in determination of their fate by constitution is deemed as right of people therefore it can be inferred that the precondition and tools for its implementation i.e. access to information has been implicitly and consequently accepted. In other words, this concept is latent in aforesaid concept of participation (Clause VIII of Article 3).

Likewise, Article 50 of IRI Constitution has mentioned typically that achievement of goals in the given article necessarily requires access to information. It has been implied about environmental protection and preservation of rights for today generation and the next generations in this article and it has assumed it as a public task. Economic activity and/ or any other activity, which destroys irrecoverably the environment, have been announced as forbidden. The environmental economic activity is done based on permission by public authorities, which may lead to environmental pollution and destruction. Based on the given article doing of public task requires public participation by people in environmental decision- making process by public authorities through access to information that is tool and precondition for this participation. In fact, with resorting to the extended interpretation as well as by considering legal rule of 'quando aliquid mandatur, mandatur et omne per quod pervenitur ad illud' (permission for parts applies to permission for the whole means) one can imply that the element of access to information is latent and inferable in text of the aforesaid articles.

Principally, access to information is exposed to some bans and secret and confidential documents. In this sense, Act of Punishment for Disclosure of Governmental and Confidential Documents (approved in 1974) is that law in which the forbidding cases of access to some of information.

In this regard, the noticeable point is that the reflected exceptions in the aforesaid law, which have been approved about 40 years ago, include relatively wide range. With respect to age of explosion of information and recognition of right of access to information, this restriction is beyond expedient level. However, there are some exceptions proposed for freedom of original information and its constraints and regularly domain of this constraint should be narrower than original range.

In Iranian legal system... the existing rules in this field have focused on banning disclosure of governmental documents and evident and information instead of reliance on principle of freedom of communication and they have appeared against transparency and responsiveness of government similar to a great obstacle. ${ }^{30}$

\subsection{Conceptual Comparison of Terms}

The in Aarhus Convention and Act regarding dissemination and free access to information, element of access to information consists of several concepts so we describe them.

A: Subject domain: Aarhus Convention is an environmental document that exclusively deals with several and various environmental matters such as climate, earth, biodiversity, and ecosystems. Although this domain is wide, it only covers environmental matters. With respect to extension and general inclusion of law, the element of access to information in Act regarding dissemination and free access to information covers several domains and including environment.

This concept is inferred from this point that in the position of expressing exceptions for access to information in addition to Articles 13-17, the law restrains the public institutions from disposal of information about governmental secrets, supporting from health and trade information, public security and comfort, and supervision over immigration to the country. Among them, Provision 1 under Clause (D) in Article 17 expresses: The subjects of Articles 13-17 do not include the information about presence or occurrence of environmental hazards and threat for public health. It is inferred from this provision that law primarily assumes environment as one of the domains of element of free access to its information. Secondly, the explained exceptions in Articles 13-17 do not include information about presence or occurrence of environmental hazards and threat for public

29 - The Aarhus Convention: An implementation Guide pp.37-38.

${ }^{30}$ - Ansari, Bagher, ibid, p 61 
health and it is excluded from banning in the aforesaid articles.

\section{B: Definition of information}

A terminological difference is visible in laws of various countries about concept of information. In some countries it has been implied about access to information while in some other countries it is referred to access to governmental documents or records.

Concept of information as in freedom of information includes all records, documents, and evidences are stored in a governmental unit regardless of saving and storage form (document, tape, electronic recorder and the like), irrespective of source (if it has been produced by public authorities and or other officials), and regardless of date of production.

Thailand has defined information very extensively in such a way it includes any type of record and background that is stored in a public institute irrespective of its form and status whether that information has been stored and classified or not. Pakistan has restricted law domain exclusively to the information used for formal purposes (governmental). The Sweden law ${ }^{31}$ also assumes only the documents for which final decision making has been done as included in freedom of information. ${ }^{32}$

In Clause III of Article 2 of Aarhus Convention it is implied: 'Environmental information means any information in written, visual, aural, electronic or any other material form on:

1) The state of elements of the environment, such as air and atmosphere, water, soil, land, landscape and natural sites, biological diversity and its components, including genetically modified organisms, and the interaction among these elements;

2) Factors, such as substances, energy, noise and radiation, and activities or measures, including administrative measures, environmental agreements, policies, legislation, plans and programs, affecting or likely to affect the elements of the environment within the scope of subparagraph (1) above, and costbenefit and other economic analyses and assumptions used in environmental decision-making

Act of dissemination and free access to information defines information in Clause- A of Article as follows: Any type of data listed in documents or stored in software and or it has been recorded by any other tool. In this definition, term 'information' has been proposed as general concept of this word without any constraint and attribute and at the same time term 'document' was implied based on its totality and finally it has embedded software and or recorded data by any other means within conceptual range of document.

It has been dealt with definition of public information in Clause III of this law and public information has been assumed as impersonal and it allegorically mentions that similar to regulations and procedures, statistics, and national and formal figures and administrative documents and correspondents are not deemed as examples for exceptions in fourth chapter in this law; however, the executive procedure of this law in Clause-A of Article 1 assumes any type of data such as sound, image, movie, written, sign, map, numbers, and a composition of them as information.

It is seen that in Act regarding dissemination and free access to information the concept and conceptual information has been implied very briefly and generally while Aarhus Convention has dealt with interpretation a lot of examples about meaning of information and applicant for acquisition of information enjoys many opportunities in selection of type of information.

\section{The Persons Who Have Right of Access to Information}

It has been mentioned about those who possess right for access to information in Clause IX of Article 3 of Aarhus Convention that: 'Within the scope of the relevant provisions of this convention, the public shall access to information, have the possibility to participate in decision-making and have access to justice in environmental matters without discrimination as to citizenship, nationality or domicile and, in the case of legal person, without discrimination as to where it has its registered seat or an effective center of its activities.'

This article deems people as owner of right for access to information. Term 'People' is a plural noun and it includes generalization. Therefore it covers all of persons and identities. Pursuant to this trend it emphasizes on lack of discrimination in various cases including discrimination in citizenship where this means that citizen of any country that $\mathrm{s} / \mathrm{he}$ is not the national of the given country, may be applicant for acquisition of information. In a part of this article where it is talked about the legal identity that includes private and public legal entities and

\footnotetext{
31 - Http//www.uniwuerz burg.de/low/swo3000.html.

32 - Ibid, pp 39-41
} 
by virtue of instruction in the latter part of this article they should not be subjected to discrimination regarding request for the given information. It is obvious that the latter part of article has noticed the legal entities since it refers to some phrases such as 'where it has its registered seat' or 'an effective center of its activities' that are related to companies and Non-Governmental Organizations (NGOs).

Article 2 of Act regarding dissemination and free access to information expresses this point with introducing those persons who have right for access to general information as follows: 'unless s/he has been legally banned for this purpose. Any Iranian person has right to access to public information. Utilization from public information or dissemination them will be subjected to the related rules and regulations.'

Perhaps this idea may strikes in mind at first place that the phrase 'Any Iranian person' is the Iranian individual i.e. natural person but with respect to terminological and legal definition of person in which it means a person who is subject of this right such as human and trading company and charity associations and government. Therefore, the person comprises of natural person (who is called human and natural person) and legal entity. ${ }^{33}$

Thus, with legal definition of person that was proposed, it includes all of Iranian natural person and legal entity. The suffix of 'Iranian' has restricted exclusively to Iranian nationals not only comprising of Iranian natural persons but also Iranian legal entities. Provided that they have been registered in Iran, commercial companies and non- governmental organizations, which are considered as Iranian included in this law and banned access of non-Iranian persons is clearly reflected in this definition.

With a brief perspective and summarized comparison among the persons as owner of right of access to information in Act regarding dissemination and free access to information with those who possess right of access to information in Aarhus Convention we may notice that Act regarding dissemination and free access to information assumes only Iranian persons to enjoy access to information while this convention assumes right of access to information all nationals from other countries without discrimination in nationality, residency, and legal residence for owner of right and this the distinctive aspect among these two laws.

\section{Obligation for Presentation of Information}

Totality of government and its information belongs to people in a democratic community and rulers and directors of community are directly or indirectly as agents and advocates for the people. Accordingly, any owner can access to his/her properties and know about quantity and quality of their administration.

If activities of government and process of decision-making are hidden from public supervision, the informed judgment and assessments of people and presses and parliaments will be difficult and even in vain. ${ }^{34}$

Right of access to information is intended to this point that each of community members may always apply for access to information that is archived in one of the public and often private institutions and that institute may reject his/her request according to the given and certain reasons. ${ }^{35}$

Accordingly, whereas public and often private institutes are centers for information storage and people have right to be aware of that information and access to it the importance of definition and recognition and types of public institutes are perfectly necessary.

With respect to legal criteria and principles it can be mentioned that public institute is an institute that possesses at least one of the following qualifications:

It has been created according to constitution or by means of ordinary law; it constitutes some part of government or belongs to government; it should be responsible for a public activity and majority portion of its budget to be provided out of public budget. With respect to above criteria, that institute is considered as public while it may have various titles in practice. For example, it may use title of ministry, organization, municipality, bank, company and foundation or institute. ${ }^{36}$

The fundamentals of freedom of expression may require all executive bodies to be included in this process. In order to maximize possibility for public access to information, definition of public bodies should be focused on type of the given service and not apparent settings and regulations.

In many countries, all three Executive, Legislature, and Judicial Faculties are assumed as included in Act of Freedom of Information but some of them have also restricted the given law to the Executive Faculty. Principally,

\footnotetext{
33 - Jafari Langeroodi, Mohammad Jafar, Law terminology, Ganj-E-Danesh, $6^{\text {th }}$ Ed, 1993, vol. 3029, p 378

34 - Ibid, pp 35-44

35 - Ibid, p 29

${ }^{36}$ - Ansari, Bagher, ibid, p 75
} 
there is no reason for exclusion of legislature and judicial faculties from the range of Act of Freedom of Information.

Thailand assumes administrative function of court exclusively included in Act of Freedom of Information.

Pakistan considers public bodies of federal government such as ministries, departments, boards, councils, courts, and bureaus as included in freedom of information and has excluded public companies and local governments from this law.

In Act of Freedom of Information at Mexico, a detailed group of obligations has been predicted for administrative bodies and the legislature and judicial faculties have been required for enforcement of them. The military and security and intelligent institutes (espionage and counterespionage) have been exempted from inclusion of Act of Freedom of Information almost in all the countries. ${ }^{37}$

Thailand law has anticipated dual and interesting dissemination project. According to this law, some information should be published in official gazette and some other is visible and available for applicants. Inversely in USA, the information for which public institutes are pledged for their dissemination should be electronically published. $^{38}$

Regarding requirement of public institutes to prepare an office that should include the existing information in them, Sweden possesses unique status and the institutions in this country should prepare the aforesaid office and put it online at public disposal. It is natural that such a measure may highly facilitate requests to access to information. ${ }^{39}$

The private institutions and including Non- Governmental Organizations (NGOs), which have acted as proxies for the government to present the public services or for any other reason, should assume their own as responsible for communication and included in these requirements caused by right of access to information. Regarding these institutions it is supposed that if the government did the assigned tasks to the private institutes per se then task for communication would be conveyed implicitly to the aforesaid institutes. Among the studied countries, South Africa has approved the best law that is concerned with inclusion of this law for private institutes. By virtue of this law, the private institutes have been defined as commercial institutes that shall disclose the needed information to protect from rights of individuals and fulfillment of their rights. ${ }^{40}$

With respect to review of the regulations for method of presentation of access to information in Aarhus Convention and comparing it with the regulations in Act regarding dissemination and free access to information regardless of the subordinates and range of their territory, the main mechanism for method of availability and access to information is approximately identical in both documents.

In general, the right of access to environmental information may be assumed conceptually in two forms: 1) the right of access to environmental information as the restricted and narrowed concept is in fact the same freedom for searching of information. According to this interpretation, the competent authorities put the requested information according to the demand by natural persons or legal entities at their disposal. In fact, this type of communication includes passive aspect since the competent officials communicate with respect to the request given by natural persons or legal entities. In other words, primarily these authorities do not put any information at disposal of individuals unless there is prior and primary request.

b) According to its extended concept, right of access to environmental information is in fact the same as right of access to information or right of receiving information. It is talked about active communication here; namely, the competent administrative authorities communicate based on their own initiative and they do not need to request from natural persons and legal entities. In other words, any citizen has right to receive the related information to the given environment without requirement to prior and primary request. ${ }^{41}$

\subsection{Aarhus Convention}

In addition to some articles about quality of the collected information and its optimization that is put at public disposal, Aarhus Convention has stipulated some instructions and emphatically warns the public authorities about their observance.

\footnotetext{
37 - Ibid, pp 77-78

38 - Ansari, Bagher, Mass media rights, SAMT Pub, Tehran, 2011, p 49

39 - Ibid, p 55

40 - Ibid, pp 43-44

41 - Ramezani Ghavam Abadi, Mohammad Hossein, Review on content of principle of participation in international environmental rights, Quarterly of legal research, vol. 29, summer 2010, pp 93-94
} 
Article 5 of convention holds: ‘

\section{Each party shall ensure that:}

(a) Public authorities possess and update environmental information which is relevant to their functions;

(b) Mandatory systems are established so that there is an adequate flow of information to public authorities about proposed and existing activities which may significantly affect the environment.'

2. Each party shall ensure that, within the framework of national legislation, the way in which public authorities make environmental information available to the public is transparent and that environmental information is effectively accessible, inter alia, by:

(a) Providing sufficient information to the public about the type and scope of environmental information held by the relevant public authorities, the basic terms and conditions under which such information is made available and accessible, and the process by which it can be obtained.

Aarhus Convention attaches special preference for dissemination quickly the information, which may lead to preservation of human life and prevention from environmental damages since under the conditions when an imminent threat may occur, the timely communication may rescue humans' life and protect from environment. In 1998, this issue was proposed in European court for human rights that it dealt with this matter. The government had committed omission about that matter in on-time dissemination of information so that thereby it could enable the citizens to evaluate the risks that were followed by living in a small town exposed to the hazards cause by adjacency to a fertilizer manufacturing factory. The court issued award in that the government has not fulfilled its obligation for communication at appropriate time.

- This articles is continued as follows:

(b) Establishing and maintaining practical arrangements, such as

(i) Publically accessible lists, registers or files;

(ii) Requiring officials to support the public in seeking access to information under this convention; and

(iii) The identification of points of contact; and

3) Each party shall ensure that environmental information progressively becomes available in electronic databases which are easily accessible to the public through public telecommunications networks. Information accessible in the form should include:

(a) Reports on the state of the environment, as referred to in [paragraph below]:

(b) Texts of legislation on or relating to the environment;

(c) As appropriate, policies, plans and programs on or relating to the environment, and environmental agreements; and

(d) Other information, to the extent that the availability of such information in this form would facilitate the application of national law implementing this convention...

4) Each party shall, at regular intervals not exceeding three or four years, publish and disseminate a national report on the state of environment, including information on the quality of the environment and information on pressures on environment.

(b) International treaties, conventions and agreements on environmental issues; and...

It is seen that the major concern for this convention that has been transferred to its members in several cases is the availability of information and updating them and notifying the procedure for access to the information. And the convention has expressed the focus point in this regard by implying this statement: 'The party shall ensure that...'. The convention notifies the members that the mandatory systems have been established in order to give adequate information to the public authorities regarding the effective environmental activity. The convention extraordinarily addresses the adequacy of the information given to the public and at same time it presented transparent procedure thereby people can acquire their given information with ease and plainly. The convention has paid special attention to this point with a lot of explanation that the files and list of records, and contact points are available to the public and to put environmental information in electronic databases via public telecommunications networks at public disposal.

Regarding identifying contact points and ways, establishment of environmental information offices is generally deemed as one of the most efficient ways for this purpose. For example, there is an institute called 'Public 
Environmental information services' in Ireland where this institute includes a library with wide database about environment. This institute puts wide levels of information at disposal of applicant as they requested. It is possible to access to wide range of this information by visiting this internet website of this institute. ${ }^{42}$

Compared to the aforesaid cases in Act regarding dissemination and free access to information, what it reflected in Aarhus Convention about obligation of members for presentation of information, is more comprehensive and pervasive to great extent. Many efforts have been made to collect the information, which is further scientific. Also it has been extremely tried to present information easily and without need to unnecessary and complex formalities and at the same time to facilitate access to information totally.

\subsection{Act Regarding Dissemination and Free Access to Information}

It can be concluded from review on current laws in our country that at present all the public institutes can be classified in four categories: Ministries, public institute, non- governmental public institute or organization, and governmental company. Each of aforesaid institutes can be called executive system. Therefore, the recent term is a general title that includes types of public institutes. ${ }^{43}$

Article 10 of Act: Regarding way of presentation of information to the public, Article 10 of Act regarding dissemination of information holds as follows:

In the course of public interest and citizenship rights, each of public institutes shall publish general information at least annually including their performance and balance sheet by means of computer facilities and in a guidance booklet as possible consisting the following items and in the case of request by citizen it should deliver this information to citizen by receiving fee:

- Objectives, tasks, policies, and procedures and structure;

- Methods and phases of fulfillment of services that the institute directly presents to members of community;

- Mechanisms for receiving complaints from citizens from decisions or measures of that institute;

- Types and forms of information, which are archived in that institute and procedure to access to them;

- Powers and tasks of its CEOs

- All mechanisms or procedures thereby natural persons and legal entities and non-governmental organizations (NGOs) can participate in execution of powers of that unit or become effective otherwise.

- With respect to forbidding entry into the domain of the classified information, this article recommends presentation of allowed information annually and in guidance manual if possible for public awareness and in line with public interest and citizenship right. Accordingly, it highlights numerous issues. The cases of application of manual (guidance book) and communication designated in this article are as follows.

- The motive for presentation of general information in a guidance book in this article: It includes public interest and typically training of citizenship rights.

- Introducing institutes and policies: In this sense, the information is given to people about structure of institute, procedures, policies, goals, powers, and tasks of CEOs and method of fulfillment of services given to the community.

- Announcement of types of the existing information: Types of information before the public authorities and existing data in institutes are given to the public and also the procedure for access to that information is notified as well.

- Method of compliant from public authorities: Mechanism of compliant from decisions made by public authorities or measures of institute is informed to citizens, natural persons, legal entities, and NGOs so that they can prepare their complaint based on the given method.

- Participation mechanism and procedure in execution of powers of institute: The public institutes shall put information about partnership procedures in execution of their power for presentation at public disposal so that natural persons, legal identities, and NGOs to be able to participate in execution of these powers or to become effective otherwise.

\footnotetext{
42 - Ibid, p 74

43 - Ansari, Bagher, Freedom of information, ibid, p 75
} 
- Article implies under the given provision that the award issued by this article for the bodies which are directly under supervision of Supreme Leader will be subjected to non- opposition of the Supreme Leader. With respect to theme of this statement, this is based on implicit agreement by Supreme Leader since the provision holds that '.... will be subjected to non- opposition of Supreme Leader'. In any case, if Supreme Leader disagrees with this issue, enforcement of this article will not be extended to the bodies, which directly supervised by Supreme Leader.

\section{Proceedings for Access to Information}

The phases of access to information should not be intolerable without rational reasons. In other words, one of the other key criteria for evaluation of validity of laws regarding freedom of information is easy, low-cost, and fast access of individuals to the information for which they search.

The comparative study on laws in various countries shows that their regulations are highly similar in terms of ease of access to information. Almost many of these countries have anticipated that demand for access should be presented in written and in some cases it may be also orally and the applicant should propose his/ her name and contact number with adequate explanation about the demanded information to the relevant institute. Some of laws have anticipated that the public institutes should appoint officers for communication in order to help the applicants for access to the needed information whenever they need. In some countries such as South Africa it has been anticipated to give help to the people, who may not present written application because of their illiteracy or physical disability. ${ }^{44}$

\subsection{Aarhus Convention}

Aarhus Convention has not attached detailed formality for way of application but at the same time the convention implies the application form that includes copies of real documentations or composed of full specifications of the requested information. This is the only sample of the application form designated by convention and furthermore in Article 4 of Clause-B, it also gives this option to the member states to make this form with another shape and it holds: 'It is reasonable for the public authority to make it available in another form, in which case reasons shall be given for making it available in that form. It is duly for this convention to assign making shape and form of request that is a formative and procedural to member states and finally to public authorities of the concluded parties.'

\subsection{Act Regarding Dissemination and Free Access to Information}

Act regarding dissemination and free access to information accepts request for access to information of the institute without any reason or justification about claim of applicant by itself regarding the procedure of access to information in second chapter, Clauses I and II and based on Articles 6-9. The public institute should answer to request for access to information as son as possible and in any case this time may not exceed later than 10 days after date of receiving request. This act is silent versus response form but the relevant procedure in the provision under Article 3 has dealt with this matter and it acknowledges as follows: The institutes including in this act shall put electronic form of) workbook and printable copy of application form of information on their website. After filling out the form and sending workbook to institute, the tracking code is put at applicant's disposal to make applicant aware of his/her request status and in Article 4 it completes these contents and adds that: The institutes including this law shall establish secure and legal relationship for execution of administrative procedure via their website so that the user to be able to communicate with the institute by means of accessible and communicational tools such as telephone, computer, and or their cellular. Acquisition of information and or presentation of paper documents and evidences shall not be subjected to presence and attendance of the citizens and owner of professions in the institutes included in this law.

It is noticeable that about shape of application form and way of completion, Aarhus Convention and Act regarding dissemination and free access to information have offered relatively similar recommendations to the members.

\section{Exceptions for Access to Information}

Among various reasons, which are employed usually for prevention from disclosure of information, one can refer to defense from national security, public health, healthcare of individuals, guiding international relations, prevention from bias in studies relating to crimes, commercial secrets, legal privileges, privacy, confidentiality of interorganizational transactions, privacy of information received from international organizations, security of communicational buildings and systems and transportation and finally efficient economic management. Freedom

44 - Ibid, pp 51-53 
of original information and constraints are some exceptions. Therefore, in determination of the governing regulations over relationship between them those rules should be followed which govern over relationship among origin and exception. No exception may be greater than its origin since exception is mainly unpleasant and rejected. The exception should not be ambiguous since the ambiguous exception is annulled. The exception should be interpreted limitedly and it should be sufficed with ensured level in determination of its terms.

Any definite decision has not been yet made about forbidding access to documents regarding the common paradigms about governmental resistance, counseling and advices of governmental high-rank officials and primary documents and administrative negotiations. Some countries and many experts in freedom of information do not accept this exception.

The legal investigations which may be conducted by justice administration, police, security officials, intelligence organizations, and administrative authorities if disclosure of information by means of each of aforesaid investigations or the given results from them (while those investigations have not been finished) damage the correctitude and health of the given investigations thereby one can prevent from disclosure of the aforesaid information. ${ }^{45}$

\subsection{Exceptions for Access to Information in Aarhus Convention}

Aarhus Convention assumes this request as refused in several cases. The given cases can be explored under two titles. One of the cases for refusing of this request is related to rejection of application formatively and the other is in terms of substantial aspect (negative effect on confidentiality)

a- The cases of refusing of request formative: In Clause III of Article 4 in this convention it implies:

Clause III: A request for environmental information may be refused if:

(a) The public authority to which the request is addressed does not hold the environmental information requested.

In fact, the requester has confused in identifying the body of holder of the designated information and as a result the requested authority and body inevitably refuses this request because it does not hold the requested information.

By virtue of Clause $\mathrm{V}$ of this article:

Clause V: Where a public authority does not hold the environmental information requested, this public authority shall, as promptly as possible, inform the applicant of the public authority to which it believes it is possible to apply for the information requested or transfer the request to that authority and inform the applicant accordingly.

Some of countries such as Ukraine, have stipulated regarding importance of communication that if the public author holds the requested information it shall inform this matter to the applicant and take the necessary measures not later than 10 days in this regard.

If the request is presented in written form or if applicant requests from authority to propose this refuse in written, therefore refused request shall be in written. Similarly, the refuse shall include the reason for rejection of request. Many countries prefer to notify the applicant by refused request in written.

For example, in Belgium the reasons for partial and or total refuse of application for information are notified to applicant in written although the request has been done orally. If the reasons for refusing of given request do not convince the applicant presentation of written refusing of request may provide this legal basis for applicant to take appeal by virtue of Article 9. In fact in Belgium, not only any type of refusing of request in written or orally should be informed to the applicant in written, but also the possibility for taking appeal should be remarked to the applicant. In France, the authorities should identify the regulations based on which the given request has been refused. ${ }^{46}$

The request lacks specific features apparently and clearly and it has been implied very generally.

Regarding application form for information, the convention has mentioned in Clause I of Article 4: the request for information should be appended to actual documentations about the requested information and or include such information. This means that that the accurate specification of the requested information such as title, number, date, and owner of document should be listed in request so that it is easy for public authority to find

45 - Ibid, pp 50-51
46 - Ibid, p 56 
them and also the content of information should totally clear and explicit. Now, if the requested information lacks the aforesaid features and it is very general then the ambiguous request will be subjected to refuse.

The request is related to the information which is going to be completed and or regarding internal relations of public authorities. Concerning first case, whereas the requested object has not achieved the final and perfect form in fact the feature of requested information has not yet emerged thus with respect to aforesaid description it may not be presented so the given request will be refused by the relevant public authority. Regarding to second case, given that the requested object is related to internal relations among public authorities therefore with respect to public interests, disclosure of this information is not feasible.

\section{$b$ - The cases of refusing request substantially (adverse effect on confidentiality)}

Clause IV of Article 4 of this convention states:

\section{'Clause IV: A request for environmental information may be refused if the disclosure would adversely affect:}

(a) The confidentiality of the proceedings of public authorities, where such confidentiality is provided for under national law...

(b) The confidentiality of commercial and industrial information, where such confidentiality is protected by law in order to protect a legitimate economic interest...

This clause has supported from commercial and industrial information. The information about production of greenhouse gases that related to environmental protection may be exception to this rule and it may be disclosed.

Confidentiality of personal information and or the files related to a natural person where that person has not agreed to disclose that information publically and confidentiality of that information is determined according to national law.

When a public authority recognizes that according to one of the stipulated exceptions, the personal information is assumed as confidential this does not mean that one can refuse from presentation of the related document totally. By virtue of this convention the public authorities shall put non- confidential parts of this information at public disposal. ${ }^{47}$

With comparing the given exceptions for access to information and its confidentiality in Act regarding dissemination and free access to information and regulations in Aarhus Convention in this regard, it is observed that the major cases of confidentiality of information in Act of dissemination are related to secret and classified governmental documents where they have been mentioned in Act of Punishment of Dissemination and Disclosure of Confidential and secret Governmental Documents. The aforesaid confidential cases have not been reflected in Aarhus Convention since Act regarding dissemination and free access to information is the domestic law in an independent country which may not be a member in Aarhus Convention and it has been approved with respect to necessity and security requisite and protection from secret governmental documents.

Nevertheless, fewer cases of exceptions for access to information are common and similar in both laws including the information relating privacy of persons and illegal disclosure of personal information about natural person, who has not been satisfied with this disclosure; disclosure of information that may threaten health of individuals; the information if it is disclosed it may lead to incurrence of financial and commercial losses and the like. Inversely, Aarhus Convention has not widely dealt with confidential documents and it seems that it has made this procedure subjected to discerning by the member states.

\subsection{Exceptions for Access to Information in Act Regarding Dissemination and Free Access to Information}

Act regarding dissemination and free access to information implies in Article-13 that: If request of applicant is related to the classified documents and information (governmental secrets) the public institutes shall refuse from presentation of such information to applicant. Access to the classified information shall be followed to the related specific rules and regulations.

\section{Governmental secrets}

The governmental secrets are some information that has been classified with observance of legal formalities by the competent public authorities. The information that can be classified as governmental secrets may be classified into various categories in terms of subject in which the foremost categories are as follows: Military secrets, economic, scientific, and technological secrets, political secrets, and information relating to espionage and counterespionage.

\footnotetext{
47 - Ibid, p 63
} 
There is no comprehensive law regarding governmental secrets in Iranian legal system. At current condition, classification of various categories of public secrets follows of Act regarding punishment and dissemination and disclosure of confidential and secret documents of government (approved in 1974) and procedure for method of archiving of confidential and secret documents of government and classification and technique of identifying type of documents and information (approved by Board of Ministers in 1975), Islamic Punishment Act, and Act of punishment of crimes for Armed Forces.

Act of punishment for dissemination and disclosure of confidential and secret documents of government has been only sufficed with presentation of definitions from confidential and secret documents of government and has anticipated punishment for their disclosure. Also procedure for method of archiving secret and confidential documents has been only concerned with some part of the governing principles and rules over governmental secrets so it has referred to them under some titles; namely, way of archiving public secrets, method of their classification, and technique of identifying type of secrets while the aforesaid items are considered only as a part of law and not total law in a comprehensive law about public secrets. ${ }^{48}$

This statement i.e. 'One who is not competent for informing about it' has been implied in

Article 3 of Act for punishment of dissemination and disclosure of confidential and secret documents of government and in provision of Article 6 of procedure for method of archiving confidential and secret documents of government etc this statement was used 'Someone who is not required to observe secret or confidential document' but it has not been identified who is competent to know the classified information and or who is required to observe secret or confidential document or to be aware of its content. This point has remained unresolved if the citizen may be included in the competent persons to know the classified documents or how one can know whether it is necessary for a citizen to be aware of the classified information or not. ${ }^{49}$

In the executive procedure for Act regarding dissemination and free access to information ${ }^{50}$ in Clause $\mathrm{T}$ of Article 1, the classified information (public secrets) has been assumed as confidential and secret documents of government as subject of act for punishment of dissemination and disclosure of confidential and secret documents of government (approved on $18^{\text {th }}$ February $1975^{51}$ ) and its executive procedure that was approved on $22^{\text {nd }}$ December $1975 .{ }^{52}$

To express and describe public documents in Article 1, Act of punishment for dissemination and disclosure of confidential and secret documents of government (approved on $18^{\text {th }}$ February $1975^{53}$ ) implies: The public documents are any type of written or registered or recorded information relating to tasks and occasions of ministries and governmental institutions and affiliates to government and governmental enterprises including post correspondents, offices, files, images, maps, clichés, charts, films, microfilms, and sound recorder tapes which have been prepared in the aforesaid bodies and or given to those bodies and it adds in the following: the secret governmental documents are those documents that their disclosure contradicts to expediencies of government and or country. The confidential public documents are those documents that their disclosure opposes to certain administrative expediencies for the aforementioned organizations in this article.

The written article divides the public documents into secret public documents and confidential public documents. The secret public documents are those documents that their disclosure opposes to expediencies of government (public policy) and or nation and confidential public documents are those ones that their disclosure contradicts to specific administrative expediencies of the given organizations in this article. With respect to the expressed definitions of public documents, this article has assumed difference among government's expediencies (public policy) with specific administrative expediencies. It seems that although public departments act as agents for the government and they are assumed as symbols for the government, here the governmental or national expediencies are proposed as their totality that at least it covers political and economic expediencies. The adverse effect of disclosure of secret public documents influences in international relations and therefore it is more important versus specific administrative expediencies. The latter expediencies include two specific and administrative features that mainly create disorder in internal affairs of the system. Procedure for method of archiving confidential and secret documents of government and classification and technique of identifying type

\footnotetext{
48 - Ansari, Bagher, Rights of media, SAMT Pub, Tehran, 2013, pp 132-133

49 - Ibid, pp 136-137

50 - Board of Ministers approved on 12/11/2014

51 - Official Gazette No 8794 dated 13/02/1975

52 - Official Gazette No 9056 dated 02/02/1975

53 - Official Gazette No 8794 dated 13/02/1975
} 
of documents ${ }^{54}$ explains about classification of documents in Article 1 as follows: confidential and secret documents of government... are classified into four groups:

First group- It includes documents that their disclosure may impose irrecoverable damage to basis of the government and foundation of state.

Second group- This class comprises of documents that their unallowed disclosure may threaten public interests and national security.

Third group- It consists of documents that their unpermitted disclosure may disrupt system of activities in organizations and make the execution of their basic tasks impossible.

Fourth group- It includes those documents which their illegal disclosure causes disorder in internal activities of an organization or contradicts to the administrative expediencies of that organization.

Secret documents are classified in first and second groups and confidential documents are categorized in third and fourth classes. Documents in first group are identified as totally secret class and documents in second group are recognized as secret class and documents in third group are titled as very confidential and documents in fourth class are characterized as confidential.

Provision- Term 'organization' in this procedure has been used instead of ministry and public institution affiliated to government and governmental enterprise.

\section{a- Privacy}

Privacy is the territory of life for any person so that typically and normally and or with prior notice the given person expects from other not to have access to information about that territory without his/ her consent or not to enter that territory and or not to look at or monitor that territory and or not to violate his/ her territory otherwise: houses and private places, body of individuals, personal information, and private communications are deemed as foremost examples of privacy. ${ }^{55}$

Right of privacy is in diversity with authoritarianism and dictatorship of governments and recognition of right of privacy mainly requires restriction of powers of government. Thus, nature of the governing states and their belief and or disbelief in necessity for recognizing such a right is especially important. Democratic political systems perceive this necessity better and more than the closed and centralized political systems. The political systems which are classified under authoritarian government may deprive individuals from their potential right of determination of fate while independent practice and self-determination in private field is one of the aspects of privacy. $^{56}$

Unlike constitutions in countries where they have supported explicitly from privacy and within framework of specific principle or principles, there is no certain text in Iranian constitution that has supported from privacy under this title. If we classify privacy in the fields of limits of vacancy and loneliness, spatial limit, information limit, communication limit, and physical limit, in IRI Constitution:

1) Possession of privacy has not been recognized as a basic right;

2) The privacy and loneliness limit has not supported either explicitly or implicitly;

3) Freedom of information has not been reflected in Article 24 of constitution except very limitedly and the exceptional cases of this freedom have been also mentioned as 'Non- violence to Islamic foundations' and 'No-violence to public rights'. ${ }^{57}$

4) 'Personal data', 'freedom of communication', and 'physical limit' have not been explicitly addressed in each of articles of Constitution under title of privacy. Even national security has not been also mentioned that is considered as the paramount exceptions for privacy. If some part of the aforesaid cases is mentioned implicitly, the emphasized exceptions i.e. 'unless based on law' are also seriously accompanied to it.

Personal data are one of the other examples of privacy. Personal data belong to private territory of individuals and they are considered as exceptions for free access to information. Thus, the public and private institutes which present public services may collect this information only if requires.

\footnotetext{
54 - Official Gazette No 9056 dated 02/02/1975

55 - Ansari, Bagher, Rights of privacy, SAMT Pub, Tehran, 2012, p 38

56 - Ibid, p 45

57 - Ibid, p 137
} 
In Article 2 of Clause-A, European Council instruction defines personal data in support from personal data: personal data include all types of information about a certain person or identity or identifiable person. The identifiable person is someone who can be identified directly or indirectly, particularly with reference to an identity number or one or more specific factors about physical, mental, subjective, economic, cultural, and or social identity. ${ }^{58}$

Unfortunately there are no certain regulations in support from these data (personal) and in our country the taste-based procedures and very different conducts are visible for collection and using personal data. ${ }^{59}$

The other important element locating within limit of privacy is national security. National security is the foremost and first constraint for freedom of expression. One can interpret national security as presence of confidence for government and citizens based on which territorial integrity or their government is not subjected to domestic or foreign threat. Namely, national security is an issue to which one can resort only in the case of threatening against cornerstones and elements of a government- nation. ${ }^{60}$

The governments may exclude some of information and institutes from requirements for freedom of expression and information to support from national security. In this regard, there is this doubt all the times that the government may abuse their powers and make most of information unsuitable for dissemination which is not really related to national security as a pretext to support from national security. To determine criteria and measures that may threaten disclosure of certain information about national security, a group of Johannesburg Principles were codified by experts in freedom of expression and national security in South Africa in October 1995. The given principles have respected for freedom of expression at high level and they tend to restrict national security to those ones which are justifiable legitimately. ${ }^{61}$

The second case of exceptions for access to information is the support from privacy.

Article 14 of Act regarding dissemination and free access to information refuses request for access to information in two cases: The first case is that if the requested information is related to privacy of individuals and the second case is when the requested information is of that type which has been acquired though breaking the laws concerning privacy.

The institutes included in this law should avoid from putting the requested information if accepting requested information causes legal disclosure of privacy about a fixed natural person.

Under certain conditions, the given institute may put the personal and confidential information at disposal of applicant including:

Third party has agreed explicitly and in written form with disclosure of information about oneself or the applicant person is the guardian, guarantor or advocate for third party. In this case with presentation of official and legal documents based on having one of the aforesaid positions with the necessary limits of powers and through ascertainment of identity, the given institute may put the requested confidential information at disposal of applicant.

If a public institute is applicant for information and the requested information is legally and directly related to legal tasks of that institute it seems in this case it necessitates acquiring description of legal tasks or the statutes of its establishment that implies goals and subject of that institute in order to receive aforesaid private information.

\section{b- Public interests and polices}

Support from heath and commercial information: Article 16 of Act regarding dissemination and free access to information implies that the institutes included in this law ascertain this point with legal documentations that presentation of the requested information may threaten life or health of individuals or cause incurrence of financial or commercial losses for them, they shall avoid from putting that information at their disposal.

Other forbidding cases for presentation of information: Article 17 of this law assumes the institutes included this law as responsible for this purpose. If the requested information damages to the following activities they should refuse from giving information.

Security and public welfare: Establishment of security and public welfare and prevention from disruption in

\footnotetext{
58 - Ibid, p 266

59 - Ibid, p 264

${ }^{60}$ - Ansari, Bagher, Rights of media, ibid, p 121

${ }^{61}$ - Ibid, pp 126-127
} 
order are some of most important tasks of government. The public institution should avoid from giving information that may disrupt security and welfare and or disturb public order.

\section{Prevention from crimes or their discovery: Arrest or prosecution of criminals}

Prevention from crimes or discovery of them is one of important duties for the Judiciary. Some part of activity of this faculty has been devoted to prevention from crime and at the same time arrest and detention and prosecution of criminals. Therefore if institute knows that presentation of information may disrupt these tasks and act as a barrier versus proper and perfect execution of these tasks it should avoid from presentation of information.

Taxation audit or legal duties or collection: Rather than oil revenue, a major portion of national income is provided from collection of taxes and legal duties so that national annual budget is mainly prepared and formulated based on these two important items of income. Whereas oil price in world markets is subjected to policies taken by industrial consumers and major oil producers and it is followed by fluctuation in oil prices; the position of taxation revenues acquires special value therefore if presentation of information by institutes included in Act regarding dissemination and free access to information tarnishes process of auditing and determination of tax or legal duties and their collection and causes tax not to be collected legally and perfectly the given institute shall avoid from presentation of the requested information.

\section{Supervision over Efficient Execution of Access to Information}

\subsection{Regulatory Institute in Aarhus Convention}

One of the features of Aarhus Convention is the procedure for supervision over observance of regulations in convention and its executive mechanisms where it has been implied in Article 15 about establishment of regulatory institute: 'The meeting of parties shall establish, on consensus basis, optional arrangements of a non-confrontational, non-judicial, and consultative nature for reviewing compliance with the provisions of this convention...' In order to review compliance of performances of members with regulations of convention, the signatories of convention elected and appointed members of regulatory (compliance) committee through creation of group-working in this regard in October 2002 during their first session of meeting of members by virtue of decision No 1/7 in addition to approval of the method of establishment of regulatory institute. The aforesaid decision requires 39 articles regarding way of establishment and performance of regulatory committee. Then in line with better performance of regulatory committee, an agendum was prepared titled Modus Operandi. By virtue of this agendum, the given committee reviews regularly the matters concerning compliance of performance of members with regulations of convention based on the acquired reports.

Supervision is done by four techniques:

1) One of the members of convention submits a report to committee about compliance of way of performance of other member with regulations of conventions.

2) One of members of convention proposes a report about compliance of way of performance of another member with regulations of convention to regulatory committee.

3) Secretariat refers a matter to regulatory committee for compliance with regulations of convention.

4) The public people give some information about method of performance to one of the members of regulatory committee for its compliance with regulations of convention.

In addition to four above-said techniques, regulatory committee may also determine compliance of performance of members with regulations of committee by its own initiative and offer some recommendations in this regard or according to request of meeting or observers act based on Clause II of Article 10 of this convention that implies:

'Clause II: At their meetings, the parties shall keep under continuous review the implementation of this convention on the basis of regular reporting by the parties, and with this purpose in mind, shall:

(a) Review the policies for and legal and methodological approaches to access to information, public participation in decision- making and access to justice in environmental matters, with a view to further improving them.'

With respect to the resulting experiences in conclusion and execution of bilateral and multilateral agreements and or other matters which are related to goals of convention and for correction of convention as per terms of Article 14 it makes decision.

According to Article 14 that is subjected to revision in convention, any member may propose some amendments for this commission and the suggested amendment text is proposed to secretariat of European Economic 
Commission for approval. The members should try for agreement over the amendment through consensus otherwise this amendment may be approved with majority of three quarters of total votes from the present members in the meeting. ${ }^{62}$

\subsection{Regulatory Institution in Act Regarding Dissemination and Free Access to Information}

In order to support from freedom of information and free access to information based on Act regarding dissemination and free access to information in public and private institutions, which provide public services and by virtue of Article 18 for codification of the needed executive plans in communication field and general supervision over good performance and removal the disorders in quality of presentation of the information as subject of this law through creation of uniform conduct, culture- building, guidance, and proposing of consultative comments, the commission of dissemination and free access to information is established by the order of president with the following arrangement:
a) Minister of communication and IT
b) Minster of intelligence
c) Minister of defense and supporting from armed forces
d) Chairman of national management and planning organization
e) Head of administrative court of justice
f) Head of cultural commission of Islamic Iran Parliament
g) Secretary of national technology supreme council

The approvals of commission of dissemination and free access to information will be binding after verification by president. Article 20 holds: the commission shall annually submit a report about observance of law in the institutes included in this law and its activities to Islamic Iran Parliament and president. In fact, Act regarding dissemination and free access to information has anticipated an executive and controlling body titled as commission of dissemination and free access to information with a specific arrangement that gives public services in line with supporting from freedom of information and public access to the existing information in public and private institutes. This commission is responsible for major tasks in description of its own tasks that seems the foremost ones are as follows: formulation of the needed executive plans for communication field and resolving dispute about way of presentation of information through creating uniformity in performance and functions.

By review in motive for establishing this commission in line with supporting from freedom of public and nonconfidential information with special arrangement and with presence of the maximum numbers of ministers and the important tasks that have been assigned to this commission and their obligation for proposing annual report to Islamic Iran Parliament and preside we may find that this commission is an promoting institute in the course of free access to public non- confidential information although the range of accessible information is limited.

Tasks of commission are so important that they also cover creating uniformity in performance. Creation of uniformity of performance is one of special tasks assigned to Supreme Court and administrative justice court as the highest judicial and administrative bodies in the country and the general board of these two supreme institutions notify their the uniform award in cases of dispute between courts and or branches of the court.

A regulatory institute has been anticipated with noticeable executive mechanism in both institutes if the supervisory regulations are duly enforced that make it possible duly to access to the presentable information. It seems that creation of regulatory institute is a part of category of access to the information presented by authorities that possess this information. What it can provide awareness for the public at maximum possible level, is the quality and quantity of a group of available information in addition to progressive technique of communication and regulatory mechanisms where they are mainly restrained by imposed limitations and exceptions under title of confidential. The domain accessible subjects should be expanded and developed by legislation of progressive laws so that to include the major portion of confidential information and the people can acquire it freely. Nature and volume of available information is more important than optimal supervision over access to it.

\section{Sanction for Access to Information (Access to Justice)}

Right of efficient compensation for loss as the concept of access to justice and compensation is found in rules of

62 - http://www.Unece.org/fileadmin/DAM/enev/pp/documents/mop1/ece.mp.pp.2.add.8.epdf 
human rights and also in environmental laws. In cases of violence to the rights protected by national or international rights, UN International Covenant on Civil and Political Rights calls up the government to provide compensatory techniques. In European convention on human rights where there is violence to the rights and freedoms listed in this convention Article 13 guarantees for their compensation. Therefore, this guarantee covers the cases of violence to right of access to information as well.

The right of compensation is not necessarily restricted to nationals from various countries. Some of international agreements include obligation for granting right of access to all administrative and judicial procedures to any loss- stricken party in equal status versus the local nationals and residents. ${ }^{63}$

\subsection{Aarhus Convention}

One of the distinct features of Aarhus Convention is the needed executive initiative mechanism versus regulations of this convention. To imply access to justice as sanction for access to information, Article 9 of this convention expresses:

'Article 9: Each party shall within the framework of its national legislation, ensure that any person who considers that his or her request for information under article 4 has been ignored, wrongfully refused, whether in part or in full, inadequately answered, or otherwise not dealt with in accordance with the provisions of that article, has access to a review procedure before a court of law or another independent and impartial body established by law.'

For the sake of more effectiveness of terms of this convention, the convention requires the members to ensure that access to information has been proposed to the public by techniques of administrative and judicial reviews.

\subsection{Act Regarding Dissemination and Free Access to Information (Access to Justice)}

Review of act regarding dissemination and free access to information and its executive procedure suggest that no matter has been explicitly mentioned about sanction on access to information in the given law.

If the public authority as holder of information totally gives partial or wrongful answer to request for information to some extent or totally refuses the request or the response of the responsible authority is intentionally against the fact and the requested information is assumed as confidential and it has been avoided from presentation of it, the Act regarding dissemination and free access to information may not determine sanction versus such a measure. Although according to Article 21 of Act regarding dissemination of owners of information and regarding dissemination of unreal information for individuals whether natural persons or legal entities they have right to disclaim it or ask for compensation of the incurred losses in accordance with general rules of civil liabilities. Likewise, concerning refuse to access to information and the similar cases, some guarantees have been stipulated in Article 22.

Nevertheless, in Article 2 of the aforesaid law, right of access to information has been formally recognized for any Iranian person and also in Article 5 it requires the public institutes to present information as subject of this law not later than 10 days after receiving the given request. It seems by virtue of general legal principles and this fact that access to information and its presentation requires right and obligation

Based on this law if right of applicant is lost in this regard although the aforesaid law has not explicitly mentioned sanction for this purpose, the applicant has right to refer to judicial courts to claim for the requested information and possible loss caused by non- receiving the given information.

\section{Conclusion}

Access to information is deemed as necessary condition for realization of public participation in process of decision-making by public authorities. In other words, access to information guarantees for efficient participation.

In fact, access to information... is the precondition for efficient public participation in decision-making and supervision over governmental activities and private sector. ${ }^{64}$

Freedom of information, democratic participation in administration of community, and judicial guarantees are considered internationally as the protected (reserved) human rights, which exist in constitutions and regional and international treaties. ${ }^{65}$

63 - Shelton, Dina, Ibid, p 90

${ }^{64}$ - Shelton, Dina, ibid, p 84

${ }^{65}$ - Kurukulasuriya, Lal et al, Fundamentals of international environmental laws, transl. Hosseini Mohammad Mehdi, Mizan Pub, 2011 , p 228 
At present, only paying attention to freedoms is no longer only responsive for social requirements of humans and creation of the needed facilities also necessitates for exploitation from freedom as human absolute rights. For this reason, generally instead of freedom of press or freedom of information in international legal declarations and treaties and covenants and new constitutions, it is talked about right of use of information or more widely about right of communication and requirement of governments to provide such rights. ${ }^{66}$

The age in which we are placed is analyzed with respect to age of explosion of information and internet ties and interactions in terms of type of specific communications and serious and seemingly inevitable consequences on individual and group life regardless of geographical, political, cultural, and economic border classifications etc in terms of globalization. ${ }^{67}$

The long-term global environmental risks and threats such as erosion of ozone (layer), and climatic changes and acid-rains may be followed by many potential risks for human life in new form. The world has exercised the political awakening in exposure to enormity and emergency of this type of international environmental problems and matters. ${ }^{68}$

This has dubbed the request of world people for access to information several times. Approval of Aarhus Convention by UN Economic Commission in Denmark on $25^{\text {th }}$ June 1998 was a response to concerns and worries of world people that had no access to information to great extent. Arhus Convention is the first multilateral environmental agreement that mainly aims at loading some obligations to both parties regarding citizens. In this way, there is close correlation among this convention and international human rights. At the same time, this correlation is reflected from procedure of supervision over observance of regulations of this convention that provided the possibility for creating a mechanism to propose report not only for governments but also for individuals also through procedure of individual legal action for the first time in international environmental laws. ${ }^{69}$

It is implied in Article 1 of this convention:

'Article 1: In order to contribute to the protection of the right of every person of present and future generations to live in an environment adequate to his or her health and well-being, each party shall guarantee the rights of access to information, public participation in decision- making, and access to justice in environmental matters in accordance with the provisions of this convention.' 70

However at international level, access to information has been formally recognized in some documents including Rio Declaration (Article 10), Agenda No 21, and so forth.

For the sake of noticeable importance of Aarhus Convention regarding the element of access to information and its executive mechanisms and supervision over observance of regulations of convention, assuming it as pattern and unique model, joining a great number of countries to this convention and acquisition of reputation at world level, the author tended to examine and compare the element of access to information in Aarhus Convention and Act regarding dissemination and free access to information (approved by Islamic Iran Parliament in 2008) in order to give answer to this question that if Act regarding dissemination and free access to information is capable and has potential to meet the due and necessary needs for community at the age of explosion of information, internet interactions, global civil society, and universality of human rights and otherwise and its inevitable effect on domestic community and national legal system of countries. By review, analysis, and comparison in this answer we found it and it was concluded that the Act regarding dissemination and free access to information might not meet the need of today community since:

The number of existing exceptions is too great remarkably for presentation of information and generally restriction of access to it in Act regarding dissemination and free access to information. The major number of the given exception is based on Act for punishment of dissemination and disclosure of secret governmental documents that has been approved in 1974 and it causes further banning of the presentable information. These exceptions for presentable information are few and limited in Aarhus Convention. As a result, the available information is presented in greater volume.

The other noticeable point is that in Act regarding dissemination and free access to information, only Iranian

\footnotetext{
${ }^{66}$ - Motamednejad, Kazem, Rights of press, $1^{\text {st }}$ vol., center for media studies and researches, 2002, pp 24-25

${ }^{67}$ - Sharifi Tarazkoohi, Hossein, Backgrounds and dimensions of citizenship rights, Tehran: Mizan Pub, 2013, p 203

68 - Mousavi, Seyed Fazlollah, ibid, p 30

${ }^{69}$ - Palmers, Mark, ibid, p 320

70 - - Aarhus Convention,op.cit.,Art.1.
} 
nationals, whether natural persons or legal identities, have right for free access to information while Aarhus Convention proposes the available information without discrimination because of nationality and foreign national including natural persons or legal entities may have access to information in member states.

In order to remove the existing major defects in Act regarding dissemination and free access to information, one should exploit from progressive and pervasive regulations and specific mechanisms of Aarhus Convention about free access to information so that to reduce size of confidential information and to present the information without discrimination in terms of nationality of the applicant and to facilitate access to the information by special mechanisms.

\section{References}

Abadi, R. G., \& Hossein, M. (2010, ). Analysis of the content of participation principle in international environmental law. Quarterly of law research, 29.

Amir Arjomand, A. (1994-1995). Environmental protection and international correlation. Journal of legal studies, Shahid Beheshti University, Tehran, 15.

Ansari, B. (2008). Freedom of information. Dadgostar Pub, Tehran.

Ansari, B. (2011). Mass communication rights. SAMT Pub, Tehran.

Ansari, B. (2012). Rights of privacy. SAMT Pub, Tehran.

Ansari, B. (2013). Rights of media. SAMT Pub, Tehran.

Carson, R. (2014). Silent spring, transl. Vahabzadeh Abdul Hossein et al, Mashhad academic jihad Pub.

Guendling, L. et al. (2002). Environmental rights, transl. Habibi Mohammad Hossein, vol. 2. Tehran University Publication.

Human rights studies center, an abstract of the foremost international human rights documents, $1^{\text {st }}$ Ed, Faculty of law \& political sciences, Tehran University, 2003.

Kiss, A. et al. (2005). Environmental rights, transl. Habibi Mohammad Hassan, Tehran University Publication.

Kurukulasuriya, L., \& Robinson, N. (2011). Fundamentals of international environmental laws, transl. Hosseini Mohammad Mehdi, Mizan Pub, Tehran.

Langeroodi, J., \& Jafar, M. (1993). Law terminology, Ganj-E-Danesh.

Motamednejad, K. (2002). Press rights (Vol. 1). studies and researches center for media, Tehran.

Mousavi, S. F. (2002). International environmental laws. Mizan Pub, Tehran.

Palmers, M. (n. d.). Regulation of environmental laws: Review of Aarhus Convention, transl. Mashhadi Ali, Legal Journal of Davar (Arbiter), 2. Law faculty, Shahid Beheshti University.

Sharifi Tarazkoohi, H. (2013). Backgrounds and dimensions of citizenship rights. Tehran, Mizan Pub.

Shelton, D., \& Kiss, A. (2010). Judicial manual of environment, transl. Abdollahi Mohsen (1st ed.). Khorsandi Pub.

Zamani, S. G. et al. (2007). The regional institutions and mechanisms to support from human rights, Shahr-E-Danesh Pub, Tehran.

\section{Copyrights}

Copyright for this article is retained by the author(s), with first publication rights granted to the journal.

This is an open-access article distributed under the terms and conditions of the Creative Commons Attribution license (http://creativecommons.org/licenses/by/3.0/). 